\title{
Studi Pemanfaatan Limbah Biomassa sebagai Raw Material Adsorben SiC dalam Penurunan Konsentrasi Amonia sebagai Parameter Bau dalam Air Limbah
}

\section{Study Utilization of Biomass Waste as SiC Adsorbent Raw Material in Decreasing Ammonia Concentrations as Odor Parameters in Wastewater}

\author{
TIA AGUSTIANI ${ }^{1,2^{*}}$, ASEP SAEFUMILLAH ${ }^{1}$, DAN HANIES AMBARSARI ${ }^{2}$ \\ ${ }^{1}$ Program Magister IImu Kimia, Departemen Kimia, Fakultas Matematika dan IImu Pengetahuan Alam, Universitas Indonesia \\ ${ }^{2}$ Pusat Teknologi Lingkungan, Badan Pengkajian dan Penerapan Teknologi \\ Email: tia.agustiani@ui.ac.id
}

\begin{abstract}
Biomass as raw material is one solution that can be developed in the management of agricultural, plantation, and industrial waste. The utilization of biomass-derived from waste can help reduce pollution and environmental pollution. This research was conducted to make Silicon Carbide (SiC) adsorbent from wood biomass using sengon sawdust as a source of carbon and non-wood biomass, namely coconut husk, as a source of silica. SiC adsorbent is applied for ammonium adsorption, which has implications on reducing ammonia gas from wastewater, reducing odor. The research methods included isolation of silica and carbon, the production of SiC adsorbent by magnesiothermic reduction, and the characterization of SiC adsorbents with XRD and SEM-EDX. Adsorption capacities of SiC to ammonium were determined according to SiO2:C adsorbent ratios (1:3 and 5:3), adsorbent mass variations, and ammonium concentrations in simulated wastewater using the spectrophotometric method. The results showed that SiC could be used as an adsorbent because there are pores on the surface structure. The optimum SiO2:C adsorbent ratio in adsorbing ammonium was 1:3 (SiC 136) with $45 \%$ adsorbed ammonium and an adsorption capacity of $0.47 \mathrm{mg} / \mathrm{g}$. The optimum adsorbent mass in adsorbing ammonium was $0.1 \mathrm{~g}$ with $41.77 \%$ adsorbed ammonium. The optimum concentration of ammonium in simulated wastewater for ammonium adsorption was $20 \mathrm{mg} / \mathrm{L}$ with $46.25 \%$ adsorbed ammonium. The adsorption isotherm pattern during the ammonium adsorption process follows the Freundlich isotherm, which means that the adsorption process occurs physically.
\end{abstract}

Keywords: adsorbent, adsorption, ammonia, biomass, coconut husk, SiC

\begin{abstract}
ABSTRAK
Biomassa sebagai raw material merupakan salah satu solusi yang dapat dikembangkan dalam pengelolaan limbah hasil pertanian, perkebunan, dan industri. Pemanfaatan biomassa yang berasal dari limbah dapat membantu mengurangi tingkat polusi dan pencemaran lingkungan. Penelitian ini dilakukan untuk membuat adsorben Silikon Carbida $(\mathrm{SiC})$ dari biomassa kayu yaitu memanfaatkan serbuk gergaji kayu Sengon sebagai sumber karbon dan biomassa non kayu yaitu sabut kelapa sebagai sumber silika. Adsorben SiC diaplikasikan dalam penjerapan amonium yang berimplikasi pada potensi penurunan gas amonia dari air limbah sehingga adsorben $\mathrm{SiC}$ berpotensi mengurangi bau dalam air limbah. Metode penelitian meliputi isolasi silika, isolasi karbon, pembuatan adsorben $\mathrm{SiC}$ secara reduksi magnesiotermik dan karakterisasi adsorben SiC dengan XRD dan SEM-EDX. Penentuan daya adsorpsi SiC sebagai adsorben terhadap variasi rasio adsorben $\mathrm{SiO}_{2}: \mathrm{C}$ (1:3 dan 5:3), variasi massa adsorben, variasi konsentrasi limbah simulasi menggunakan metode spektrofotometri. Hasil penelitian menunjukkan bahwa SiC dapat digunakan sebagai adsorben karena terdapat poripori pada struktur permukaan. Variasi rasio adsorben $\mathrm{SiO}_{2}: \mathrm{C}$ optimum dalam mengadsorpsi amonium ialah SiC 136 dengan amonium teradsorpsi sebanyak 45\% dan kapasitas adsorpsi sebesar 0,47 mg/g. Massa adsorben optimum dalam mengadsorpsi amonium ialah $0,1 \mathrm{~g}$ dengan amonium teradsorpsi $41,77 \%$. Konsentrasi optimum limbah simulasi dalam adsorpsi amonium $20 \mathrm{mg} / \mathrm{L}$ dengan amonium teradsorpsi $46,25 \%$. Pola isoterm adsorpsi selama proses adsorpsi amonium mengikuti isoterm Freundlich, yang berarti proses adsorpsi cenderung terjadi secara fisika.
\end{abstract}

Kata kunci: adsorben, adsorpsi, amonia, biomassa, sabut kelapa, SiC 


\section{PENDAHULUAN}

\subsection{Latar Belakang}

Biomassa adalah bahan organik yang tersedia secara terbarukan dan diproduksi langsung atau tidak langsung oleh organisme hidup tanpa kontaminasi dari zat lain atau limbah. Limbah hutan dan pabrik, tanaman pertanian dan limbah kayu, kotoran hewan, limbah operasi ternak, tanaman air, pertumbuhan pohon dan tanaman, serta sampah kota dan industri adalah termasuk biomassa. Pada dasarnya biomassa dikelompokkan menjadi tiga kelompok besar, yaitu biomassa kayu, biomassa bukan kayu, dan bahan bakar sekunder ${ }^{(1)}$.

Kelapa (Cocos nucifera L.) adalah salah satu tanaman penghasil biomassa non kayu dari sabutnya. Luas perkebunan kelapa nasional pada tahun 2020 mencapai 3.377.376 hektar dengan produksi kelapa per tahun 2020 sebanyak 2.798 .980 ton $^{(2)}$. Sekitar $35 \%$ buah kelapa merupakan sabut kelapa. Dari 16.000 butir kelapa dapat menghasilkan $2.800 \mathrm{~kg}$ serat sabut(3). Jika tidak dikelola dengan baik maka akan menimbulkan limbah yang akan mencemari lingkungan. Sabut kelapa mempunyai komposisi serat kasar 30,34\%, selulosa $32,69 \%$, hemiselulosa $22,56 \%$, lignin $42,10 \%$, dan kadar air $5,43 \%{ }^{(4)}$. Sabut kelapa memiliki potensi besar sebagai sumber silika $\left(\mathrm{SiO}_{2}\right)$ alternatif dari produk limbah perkebunan ${ }^{(5)}$.

Kemudian salah satu bentuk biomassa non kayu ialah serbuk gergaji kayu. Industri mebel banyak menggunakan bahan kayu berkualitas tinggi dalam produksinya. Salah satu kayu yang sering digunakan adalah Sengon (Paraserianthes falcataria). Industri ini menghasilkan limbah yang belum secara maksimal dimanfaatkan oleh masyarakat, salah satunya yaitu serbuk gergaji. Produksi serbuk gergaji kayu di Indonesia adalah sebesar 1.217.868 $\mathrm{m}^{3}$ dengan densitas $600 \mathrm{~kg} / \mathrm{m}^{3}$ sehingga didapatkan bobot limbah serbuk gergaji sekitar 730.720 .800 ton $^{(6)}$. Komponen kimia yang terdapat pada kayu adalah karbohidrat, lignin, dan zat ekstraktif. Struktur kimia ketiga komponen tersebut tersusun atas karbon, hidrogen, dan oksigen. Berdasarkan komponen kimianya, maka serbuk gergaji kayu ini berpotensi sebagai sumber karbon yang dapat diolah dan dimanfaatkan menjadi sesuatu yang lebih bernilai dan tidak mencemari lingkungan.

Limbah biomassa berupa sabut kelapa dan serbuk gergaji kayu tersebut dapat dimanfaatkan sebagai raw material dalam pembuatan adsorben SiC (Silikon Carbida). Dimana saat ini pembuatan SiC dari bahan alam sedang banyak diminati baik cara mendapatkan bahan dasar silika maupun karbon. Selama ini sintesis SiC menggunakan sumber karbon dalam bentuk grafit, karbon black maupun batu bara serta sumber silika dari mineral-mineral alamiah seperti kuarsa dan batuan. Sumber-sumber tersebut merupakan bahan alam yang tidak dapat diperbaharui sehingga akan habis. Maka dari itu saat ini beberapa peneliti melakukan penelitian dengan memanfaatkan limbah pertanian, perkebunan, dan industri sebagai sumber silika dan karbon. SiC dapat dipreparasi secara reduksi karbotermal dari bambu arang sebagai sumber karbon yang diaplikasikan sebagai komposit keramik ${ }^{(7)}$. Selain itu pemanfaatan sekam padi yang dikonversi menjadi SiC sebagai sumber $\mathrm{Si}$ dan $\mathrm{C}$ dengan metode magnesiotermik sudah dilakukan ${ }^{(8)}$. Namun belum dilakukan pembuatan $\mathrm{SiC}$ dari sumber silika limbah pertanian lain seperti dari sabut kelapa yang memiliki potensi sebagai sumber silika.

SiC yang diperoleh dari raw material biomassa diaplikasikan sebagai adsorben dalam air limbah. Salah satunya air limbah industri nata de coco yang merupakan salah satu industri yang memanfaatkan bahan baku air buah kelapa. Akhir-akhir ini pemanfaatan bahan baku air kelapa untuk Agroindustri nata de coco mengalami peningkatan. Perkembangan jumlah Agroindustri nata de coco mengakibatkan semakin besarnya limbah yang dihasilkan ${ }^{(9)}$. Limbah yang dihasilkan dari aktivitas industri nata de coco sulit dihindari, terutama limbah air yang digunakan dalam proses perendaman. Air limbah ini bersifat asam karena mengandung asam asetat dalam konsentrasi tinggi ${ }^{(10)}$. Air limbah sisa fermentasi yang memiliki bau tidak sedap ini menyebabkan pencemaran air karena masih mengandung sejumlah bahan terlarut seperti amonium. SiC hasil preparasi dari silika sabut kelapa dan karbon serbuk gergaji kayu Sengon diaplikasikan sebagai adsorben. Hal ini karena $\mathrm{SiC}$ mempunyai karakter pori yang umum dimiliki oleh adsorben lain. Sehingga diharapkan $\mathrm{SiC}$ dapat mengadsorpsi amonium dan menurunkan kadar amonia sebagai parameter bau dalam limbah industri nata de coco. Sehingga diharapkan dapat diterapkan dalam adsorpsi amonium pada limbah asli industri nata de coco.

\subsection{Tujuan Penelitian}

Tujuan penelitian ini adalah mengkaji potensi limbah biomassa sabut kelapa dan serbuk gergaji kayu Sengon sebagai raw material dalam pembuatan adsorben $\mathrm{SiC}$, mengetahui daya adsorpsi SiC terhadap konsentrasi amonium dalam air limbah dan mengetahui pola isoterm adsorpsi SiC dalam mengadsorpsi amonium. 


\section{BAHAN DAN METODE}

Penelitian ini dilaksanakan di Laboratorium Pusat Teknologi Lingkungan (PTL), Badan Pengkajian dan Penerapan Teknologi (BPPT), Puspiptek, Tangerang Selatan. Adsorpsi amonium oleh adsorben SiC dilakukan dalam sistem batch dengan cara menambahkan adsorben $\mathrm{SiC}$ dengan massa tertentu ke dalam air limbah simulasi berupa larutan $\mathrm{NH}_{4} \mathrm{OH}$.

\subsection{Bahan dan Alat}

Bahan-bahan yang digunakan dalam penelitian ini antara lain adalah sabut kelapa dan serbuk gergaji kayu Sengon yang diperoleh dari daerah Ciamis, Jawa Barat, serbuk magnesium (Mg) produksi Merck, $\mathrm{H}_{2} \mathrm{SO}_{4} \quad 96 \%$ produksi Malinckrodt Baker Inc. $\mathrm{HCl} 37 \%$, dan $\mathrm{NH}_{4} \mathrm{OH}$ produksi Malinckrodt Baker Inc serta kertas saring Whatman No. 42.

Peralatan yang digunakan dalam penelitian antara lain peralatan gelas, neraca analitik (Sartorius CP224S), furnace (Thermolyne Type 47900), magnetic stirrer (IKA C-MAG HS 10), spektrofotometer UV-Vis (Jasco V-530), XRF (Rigaku nex cg), XRD (Miniflex), dan SEM-EDX (Desktop SEM Thermofisher - Phenom Pro X).

\subsection{Pembuatan Adsorben SiC}

Tahap pertama, isolasi silika dari sabut kelapa $^{(5)}$. Sabut kelapa ditimbang kemudian sabut kelapa dicuci sebanyak lima kali yang mana empat kali dengan air ledeng selanjutnya satu kali dengan akuades. Sabut kelapa dikeringkan di dalam oven pada suhu $120{ }^{\circ} \mathrm{C}$ untuk menghilangkan kotoran dan kelembaban. Sabut kelapa yang sudah bersih ditempatkan pada cawan porselen dan dipanaskan pada suhu $700^{\circ} \mathrm{C}$ selama 2 jam dalam furnace. Selanjutnya dikenakan perlakuan asam dengan penambahan $\mathrm{H}_{2} \mathrm{SO}_{4} \quad 5 \quad \mathrm{~N}$ dalam gelas piala. Larutan dipanaskan hingga suhu $50{ }^{\circ} \mathrm{C}$ dan diaduk dengan hot plate magnetic stirrer secara terus menerus selama 1 jam. Setelah proses leaching, larutan disaring dan residu dicuci beberapa kali dengan akuades untuk menghilangkan kandungan asam pada abu. Residu abu dikeringkan pada suhu $70{ }^{\circ} \mathrm{C}$ selama 2 jam dalam oven untuk memperoleh bubuk silika. Silika hasil isolasi dikarakterisasi dengan menggunakan X-Ray Fluorescence (XRF) untuk mengetahui persentase massa silika.

Tahap kedua, isolasi karbon dari serbuk gergaji kayu Sengon ${ }^{(11)}$. Serbuk diolah menjadi arang. Proses pengarangan dilakukan dalam reaktor selama 5 jam pada suhu $500{ }^{\circ} \mathrm{C}$ tanpa adanya oksigen. Bobot serbuk kayu Sengon yang digunakan sebanyak $1.300 \mathrm{~g}$ yang sebelumnya dilakukan pengukuran kadar air. Bobot arang yang diperoleh ditimbang untuk menentukan rendemennya. Hasil isolasi dikarakterisasi dengan XRD dan SEM-EDX.

Tahap ketiga, pembuatan adsorben SiC dengan variasi rasio $\mathrm{SiO}_{2}: \mathrm{C} 1: 3$ dan $5: 3^{(8,11)}$. Dicampurkan silika dari sabut kelapa $\left(\mathrm{SiO}_{2}\right)$ dan karbon dari serbuk gergaji (C) dengan variasi rasio $\mathrm{SiO}_{2}: \mathrm{C}$ yaitu $1: 3$ dan $5: 3$ serta penambahan bubuk magnesium (rasio Si:Mg adalah 1:0,5). Campuran serbuk digerus menggunakan mortar dan alu. Sampel dipanaskan dalam furnace pada temperatur $600{ }^{\circ} \mathrm{C}$ dengan waktu pemanasan 6 jam. Serbuk yang diperoleh selanjutnya dicuci menggunakan $\mathrm{HCl}$ pekat dan diaduk menggunakan magnetic stirrer. Endapan disaring dan dikeringkan menggunakan hot plate pada temperatur $180{ }^{\circ} \mathrm{C}$ selama 1 jam sehingga diperoleh serbuk SiC 136 dan SiC 536. Kedua $\mathrm{SiC}$ dikarakterisasi dengan Scanning Electron Microscopy (SEM) - Energy Dispersive X-Ray (EDX) untuk melihat struktur mikro dan menganalisis jenis unsur material berdasarkan tingkat energi dan $X$-ray Diffraction (XRD) untuk mengetahui fasa dan ukuran kristal SiC.

\subsection{Daya Adsorpsi SiC}

\subsubsection{Variasi Rasio Adsorben}

Penentuan variasi rasio optimum adsorben dilakukan dengan cara mengambil $10 \mathrm{ml}$ larutan $\mathrm{NH}_{4} \mathrm{OH}$ dengan konsentrasi $10 \mathrm{mg} / \mathrm{L}$ kemudian dimasukkan ke dalam botol berbeda label untuk SiC 136 dan SiC 536. Selanjutnya ditimbang $0,1 \mathrm{~g}$ adsorben SiC 136 serta SiC 536 dan masing-masing ditambahkan ke dalam tiap botol berbeda label serta diaduk pada kecepatan 100 rpm selama 15 menit menggunakan shaker. Setelah selesai, larutan disaring dengan kertas saring Whatman No. 42 dan filtratnya diuji untuk parameter amonium secara spektrofotometri.

\subsubsection{Variasi Massa Adsorben}

Penentuan massa adsorben optimum dilakukan dengan mengambil larutan $\mathrm{NH}_{4} \mathrm{OH}$ dengan konsentrasi $10 \mathrm{mg} / \mathrm{L}$ sebanyak $10 \mathrm{~mL}$ dan dimasukkan ke dalam botol berbeda label untuk SiC 136 dan SiC 536. Kemudian setiap adsorben $\mathrm{SiO}_{2}: \mathrm{C}$ dengan variasi massa $0,05 \mathrm{~g}$; $0,1 \mathrm{~g} ; 0,2 \mathrm{~g}$ ditambahkan ke dalam botol berbeda label tersebut. Pengujian dilakukan secara triplo. Larutan diaduk dengan shaker pada kecepatan $100 \mathrm{rpm}$ selama 15 menit. Setelah selesai, larutan disaring dengan kertas saring Whatman No. 42 dan filtratnya diuji parameter amonium secara spektrofotometri.

\subsubsection{Variasi Konsentrasi Adsorbat}

Penentuan konsentrasi larutan sampel $\mathrm{NH}_{4} \mathrm{OH}$ optimum sebagai adsorbat dilakukan dengan cara mengambil larutan $\mathrm{NH}_{4} \mathrm{OH}$ sebanyak $10 \mathrm{~mL}$ dengan variasi konsentrasi 10 , $20,30,40,50$, dan $60 \mathrm{mg} / \mathrm{L}$ kemudian 
dimasukkan ke dalam botol. Pengujian dilakukan secara triplo. Sampel dikontakkan dengan adsorben $\mathrm{SiO}_{2}: \mathrm{C}$ rasio optimum dan massa optimum yang diperoleh dari tahap sebelumnya serta diaduk dengan shaker pada kecepatan 100 rpm selama 15 menit. Setelah selesai, larutan disaring dengan kertas saring Whatman No. 42 dan filtratnya diuji parameter amonium secara spektrofotometri.

\subsubsection{Penentuan Pola Isoterm Adsorpsi}

Penentuan pola isoterm adsorpsi dilakukan dengan cara mengambil larutan $\mathrm{NH}_{4} \mathrm{OH}$ sebanyak $10 \mathrm{~mL}$ dengan variasi konsentrasi 10 , $20,30,40,50$, dan $60 \mathrm{mg} / \mathrm{L}$ kemudian dimasukkan ke dalam botol. Pengujian dilakukan secara triplo. Sampel dikontakkan dengan adsorben $\mathrm{SiO}_{2}: \mathrm{C}$ rasio optimum dan massa optimum. Proses pengontakkan diaduk dengan shaker pada kecepatan $100 \mathrm{rpm}$ selama 15 menit. Setelah selesai, masing-masing larutan disaring dengan kertas saring Whatman No. 42 dan filtratnya diuji untuk parameter amonium secara spektrofotometri. Selanjutnya dilakukan analisis pola isoterm adsorpsi Langmuir dan Freundlich.

\section{HASIL DAN PEMBAHASAN}

\subsection{Isolasi Silika dari Sabut Kelapa}

Silika dari sabut kelapa diisolasi melalui tahap pencucian, pengeringan, pengabuan, dan pemurnian sehingga diperoleh serbuk silika murni. Kandungan silika sabut kelapa hasil isolasi dianalisis secara kuantitatif menggunakan XRF untuk mengetahui kandungan silika dari sabut kelapa dan oksida-oksida lainnya. Tabel 1 menunjukkan silika sabut kelapa dengan kemurnian $61,5 \%$ dan $38,5 \%$ sisanya berupa senyawa-senyawa oksida yang tidak bisa dihilangkan.

Tabel 1 Hasil analisis kuantitatif silika sabut kelapa menggunakan XRF

\begin{tabular}{clclc}
\hline No & Senyawa & $\begin{array}{c}\text { Persentase } \\
\text { Berat }\end{array}$ & Unsur & $\begin{array}{c}\text { Persentase } \\
\text { Berat }\end{array}$ \\
\hline 1 & $\mathrm{SiO}_{2}$ & 61,5 & $\mathrm{Si}$ & 36,9 \\
2 & $\mathrm{Al}_{2} \mathrm{O}_{3}$ & 0,534 & $\mathrm{Al}$ & 0,387 \\
3 & $\mathrm{~K}_{2} \mathrm{O}$ & 4,33 & $\mathrm{~K}$ & 4,60 \\
4 & $\mathrm{MgO}$ & 0,606 & $\mathrm{Mg}$ & 0,482 \\
5 & $\mathrm{Fe}_{2} \mathrm{O}_{3}$ & 2,18 & $\mathrm{Fe}$ & 1,89 \\
6 & $\mathrm{MnO}_{2}$ & 0,0606 & $\mathrm{Mn}$ & 0,0570 \\
7 & $\mathrm{P}_{2} \mathrm{O}_{5}$ & 0,117 & $\mathrm{P}$ & 0,0685 \\
8 & $\mathrm{Cl}$ & 0,0148 & $\mathrm{Cl}$ & 0,0148 \\
9 & $\mathrm{CuO}$ & 0,0311 & $\mathrm{Cu}$ & 0,0302 \\
10 & $\mathrm{SO}_{3}$ & 0,183 & $\mathrm{~S}$ & 0,0978 \\
11 & $\mathrm{TiO}_{2}$ & 0,0574 & $\mathrm{Ti}$ & 0,0550 \\
12 & $\mathrm{Co}_{2} \mathrm{O}_{3}$ & 0,0124 & $\mathrm{Co}$ & 0,0108 \\
13 & $\mathrm{NiO}$ & 0,106 & $\mathrm{Ni}$ & 0,105 \\
\hline
\end{tabular}

\subsection{Isolasi Karbon dari Serbuk Gergaji Kayu Sengon}

Karbon yang digunakan dalam sintesis SiC diisolasi dari serbuk gergaji kayu Sengon melalui proses pengarangan serbuk gergaji kayu pada suhu $500{ }^{\circ} \mathrm{C}$ tanpa adanya oksigen. Massa serbuk gergaji kayu yang digunakan sebanyak $1.300 \mathrm{~g}$ dengan kadar air serbuk gergaji kayu $11,5 \%$. Serbuk arang yang dihasilkan sebanyak $350 \mathrm{~g}$ sehingga diperoleh rendemen arang kering sebesar $32,77 \%$. Nilai rendemen tersebut mendekati nilai rendemen arang kering yang dihasilkan dari kayu lembasung yaitu $37,67 \%\left({ }^{(11)}\right.$.

Struktur mikro permukaan arang dianalisis menggunakan SEM. Sedangkan EDS menganalisa jenis unsur material berdasarkan tingkat energi. Sehingga teknik analisis SEM yang digabungkan dengan EDS dapat mengidentifikasi unsur-unsur yang dimiliki oleh fasa yang terlihat pada gambar struktur mikro. Kandungan unsur-unsur tersebut dapat diperoleh secara kualitatif bahkan semikuantitatif. Penampakan morfologi serbuk arang hasil isolasi terlihat homogen dan terdapat pori-pori di permukaannya (Gambar 1). Gambar 1.b merupakan morfologi permukaan arang pada perbesaran 10.000 kali. Hasil analisis menunjukkan permukaan yang halus dan adanya partikel berbentuk flakes/sferik yang tidak seragam $^{(12)}$. Analisis EDS pada karbon hasil isolasi dari serbuk gergaji kayu Sengon menunjukkan bahwa konsentrasi atom $\mathrm{C}$ adalah $88.98 \%$ dengan berat massa $85,84 \%$ (Gambar 2). Selain atom $\mathrm{C}$, terdeteksi juga atom $\mathrm{O}$ dengan konsentrasi sebesar $11,02 \%$ dengan berat massa $14,16 \%$. Sebaran karbon dan oksigen pada permukaan arang hasil isolasi dapat dilihat pada Gambar 3. Karbon dan oksigen tersebar merata di permukaan yang ditandai dengan warna merah untuk karbon dan warna kuning untuk oksigen.
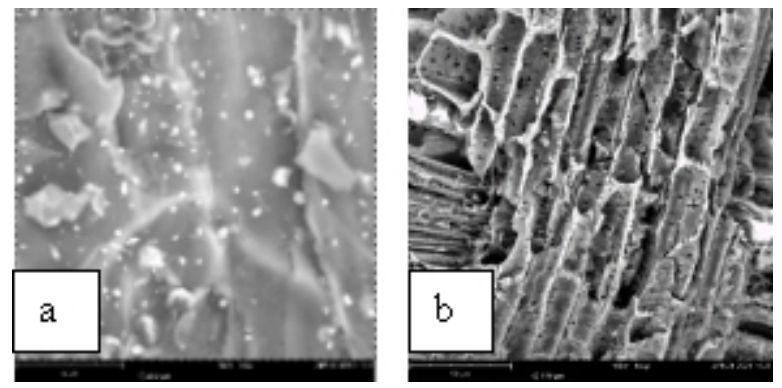

Gambar 1. Morfologi permukaan karbon dari serbuk gergaji kayu Sengon, perbesaran (a) 1.500 kali dan (b) 10.000 kali 


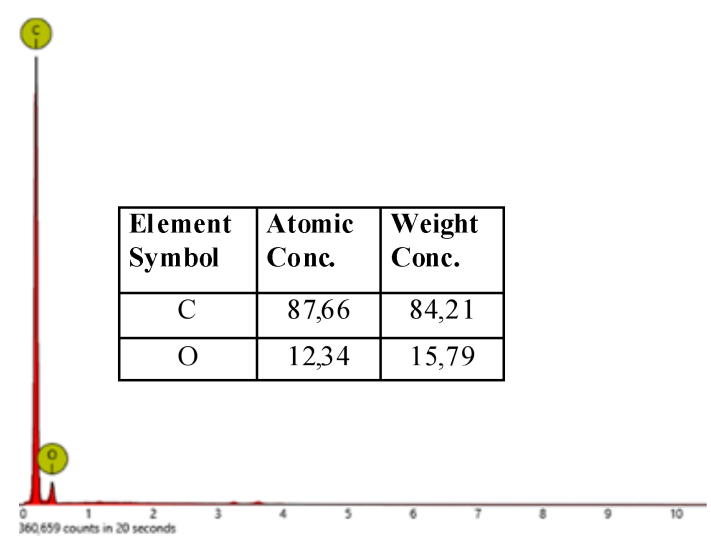

Gambar 2. Kurva EDX serbuk arang
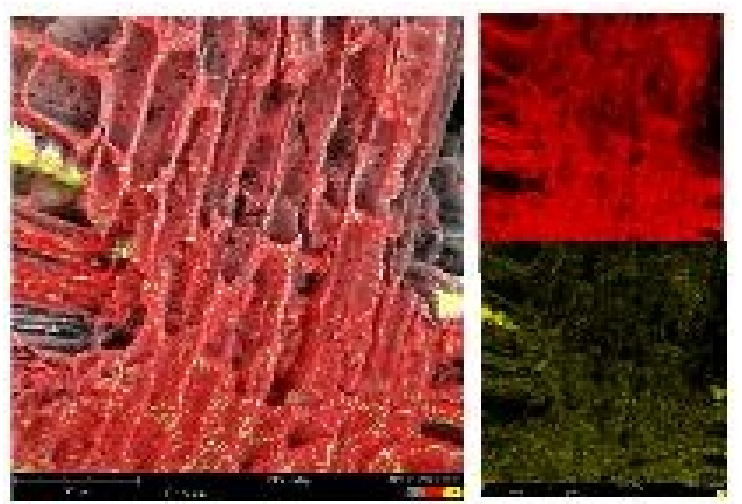

Gambar 3. Sebaram karbon pada permukaan serbuk arang pada perbesaran 1.500 kali

Analisis X-ray diffraction (XRD) serbuk arang dari serbuk gergaji kayu Sengon dilakukan dengan sumber sinar-X $\mathrm{Cu}-\mathrm{Ka} 1$ dengan panjang gelombang $1.540593 \AA$. Analisis dilakukan dengan sudut $2 \theta$ mulai dari $0^{\circ}$ sampai dengan $90^{\circ}$. Difraktogram pada Gambar 4 menunjukkan bahwa karbon hasil isolasi dari serbuk gergaji kayu Sengon sebagian besar masih bersifat amorf dalam fasa grafit.

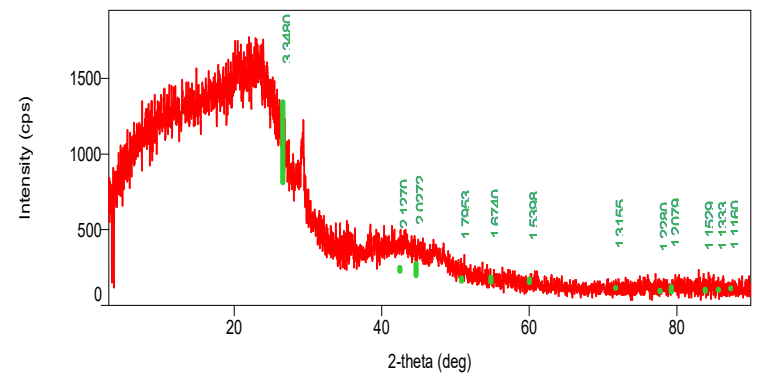

Gambar 4. Pola difraksi untuk karbon serbuk gergaji kayu Sengon

\subsection{Pembuatan Adsorben SiC}

Silikon karbida pada penelitian diperoleh dari hasil reaksi antara silika yang diisolasi dari sabut kelapa dan karbon dari serbuk gergaji kayu
Sengon. Metode yang digunakan yaitu metode reduksi magnesiotermik. Reaksi yang terjadi sebagai berikut ${ }^{(13)}$ :

$$
\begin{aligned}
& \mathrm{SiO}_{2}(\mathrm{~s})+2 \mathrm{Mg}(\mathrm{g}) \rightarrow 2 \mathrm{MgO}(\mathrm{s})+\mathrm{Si}(\mathrm{s}) \\
& \mathrm{SiO}_{2}(\mathrm{~s})+2 \mathrm{C}(\mathrm{s}) \rightarrow \mathrm{SiC}(\mathrm{s})+\mathrm{CO}_{2}(\mathrm{~g}) \\
& \mathrm{SiO}_{2}(\mathrm{~s})+3 \mathrm{C}(\mathrm{s}) \rightarrow \mathrm{SiC}(\mathrm{s})+2 \mathrm{CO}(\mathrm{g})
\end{aligned}
$$

Pembuatan $\mathrm{SiC}$ dengan variasi rasio $\mathrm{SiO}_{2}: \mathrm{C}$ 1:3 dan 5:3 menunjukkan ciri fisik yang berbeda. SiC yang diperoleh memiliki ciri warna abu kehijauan dan hijau. Pada rasio $\mathrm{SiO}_{2}: \mathrm{C}$ 1:3 menunjukkan warna abu kehijauan sedangkan rasio $\mathrm{SiO}_{2}: \mathrm{C}$ 5:3 menunjukkan warna hijau (Gambar 5). Warna hijau menandakan adanya kandungan $\mathrm{SiC}^{(14)}$.
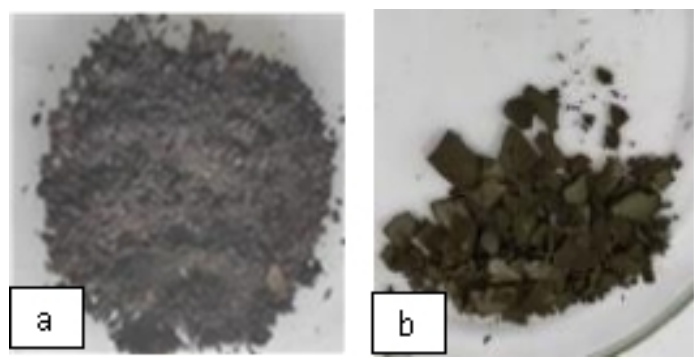

Gambar 5 Adsorben SiC dengan variasi Si:C 1:3 (SiC 136) (a) dan (SiC 536 (b)

Tabel 2. Sudut $2 \theta$ dan ukuran kristal SiC 136

\begin{tabular}{lcccc}
\hline Adsorben & $\begin{array}{c}\text { Nomor } \\
\text { Puncak }\end{array}$ & $\begin{array}{c}\mathbf{2 \theta} \\
\text { (deg.) }\end{array}$ & $\mathbf{d}[\mathbf{A}]$ & $\mathbf{D}$ (nm) \\
\hline SiC 136 & 1 & 21,78 & 4,081 & 40,46 \\
& 2 & 28,28 & 3,156 & 27,25 \\
& 3 & 47,40 & 1,918 & 108,1 \\
& 4 & 56,14 & 1,638 & 64,17 \\
SiC 533 & 1 & 22,08 & 4,023 & 40,48 \\
& 2 & 28,76 & 3,102 & 68,13 \\
& 3 & 47,66 & 1,907 & 108,2 \\
& 4 & 56,44 & 1,629 & 74,88 \\
\hline
\end{tabular}

Terdapat pergeseran puncak difraksi antara rasio $\mathrm{SiO}_{2}: \mathrm{C}$ 1:3 dan 5:3. Ukuran kristal SiC 136 bervariasi pada rentang $27 \mathrm{~nm}$ sampai dengan $108 \mathrm{~nm}$. Sedangkan rentang ukuran kristal SiC 536 di antara $40 \mathrm{~nm}$ sampai dengan $108 \mathrm{~nm}$. Maka kristal SiC 536 memiliki kisaran ukuran kristal yang lebih besar dibandingkan dengan $\mathrm{SiC}$ 136. Selanjutnya pada penentuan fasa SiC dilakukan dengan menggunakan software MATCH. Berdasarkan hasil analisis diketahui bahwa fasa SiC 136 dan SiC 536 ialah silikon karbida Moissanite 3C (3C-SiC atau $\beta-S i C)$. 3C$\mathrm{SiC}$ dikenal sebagai politipe temperatur

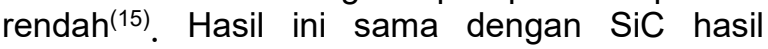
sintesis silika dari sekam padi ${ }^{(8)}$. Dengan metode yang sama $\mathrm{SiC}$ dari silika sekam padi dan silika sabut kelapa memiliki struktur kubik. 


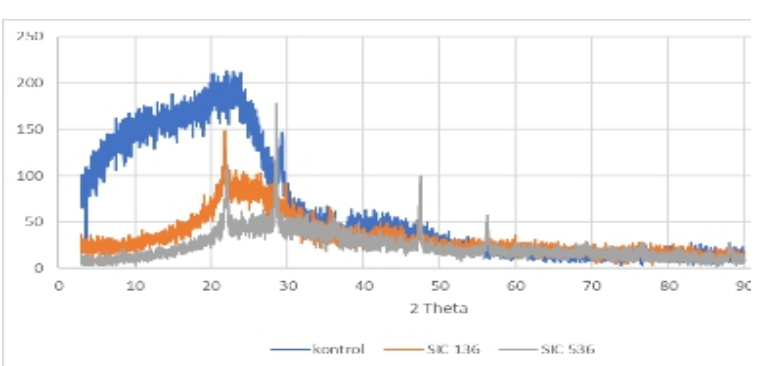

Gambar 6. Pola difraksi SiC 136 dan SiC 536

Hasil analisis menggunakan SEM ditunjukkan pada Gambar 7. Adanya perbedaan morfologi antara SiC 136 dan 536 yaitu pada permukaan SiC 136 silikon berkumpul membentuk suatu bulatan yang diikelilingi oleh karbon dan juga terindikasi adanya karbon yang belum bereaksi. Sedangkan pada permukaan SiC 536 silikon dan karbon tersebar merata.
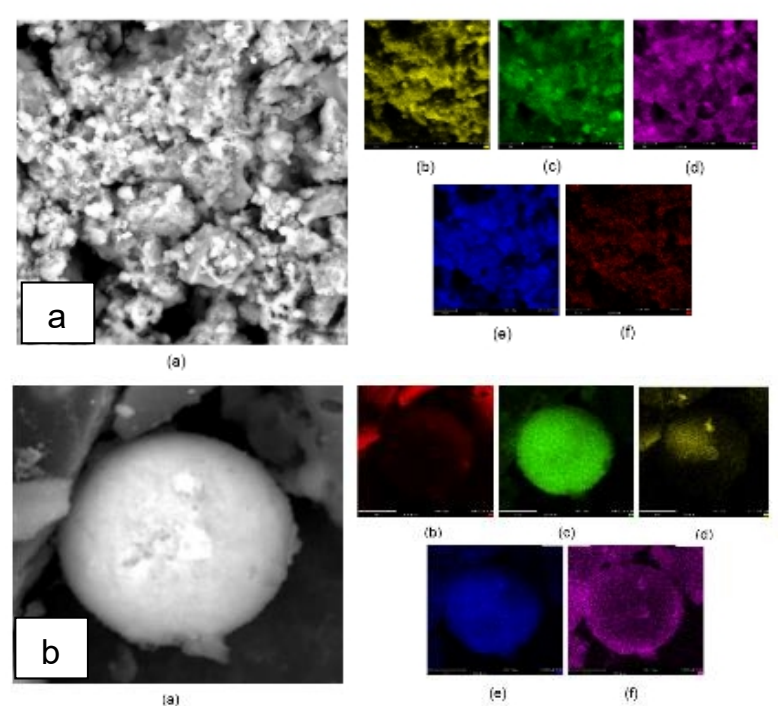

Gambar 7 Morfologi permukaan SiC 136 (A), $\mathrm{SiC} 536(\mathrm{~B})$

Kurva EDX pada Gambar 8 menunjukkan perbandingan atom unsur Si:C $=10,72: 73,76$, hasil tersebut menunjukkan bahwa pada $\mathrm{SiC} 136$ unsur $\mathrm{Si}$ lebih sedikit dibandingkan unsur $\mathrm{C}$. Perbandingan unsur Si dan $C$ ini tidak sesuai dengan perhitungan stoikiometri. Hal tersebut disebabkan oleh adanya pengotor-pengotor lain yang terdeteksi seperti $\mathrm{Mg}, \mathrm{Cl}$, dan $\mathrm{O}$. Perbandingan atom unsur Si:C pada SiC 536 ialah 15,50:12,39 (Gambar 9), hal ini menunjukkan bahwa unsur $\mathrm{Si}$ lebih banyak dibandingkan dengan unsur $C$. Perbandingan unsur $\mathrm{Si}$ dan $\mathrm{C}$ ini pun tidak sesuai dengan perhitungan stoikiometri, hal ini mengindikasikan adanya unsur-unsur pengotor sama halnya pada SiC 136.

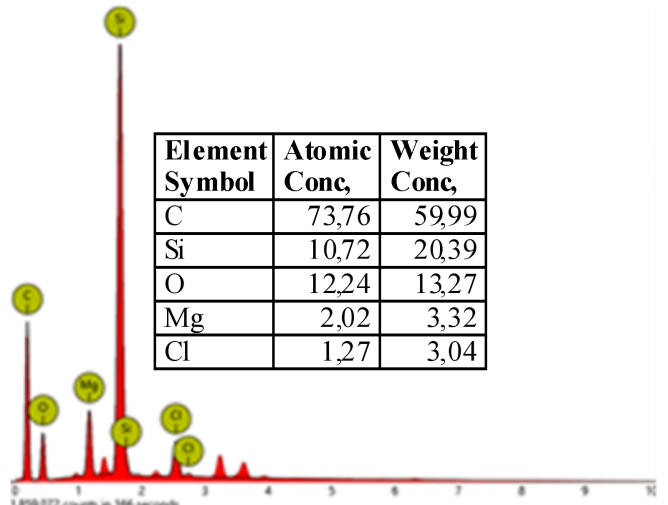

Gambar 8. Kurva EDX SiC 136

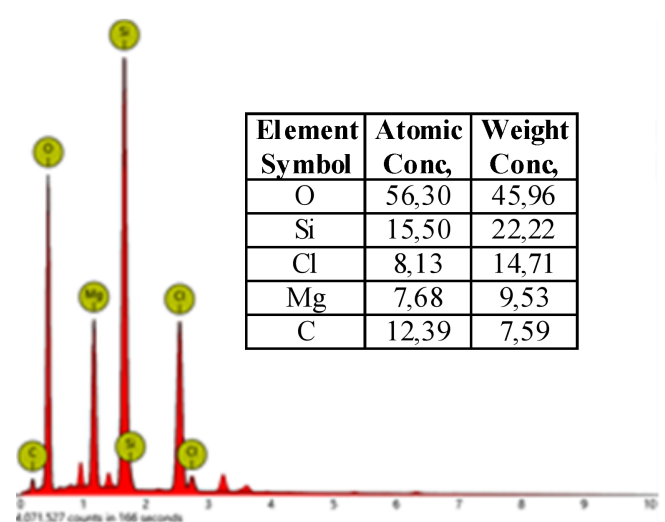

Gambar 9. Kurva EDX SiC 536

\subsection{Daya Adsorpsi SiC terhadap Amonia}

Amonia $\left(\mathrm{NH}_{3}\right)$ merupakan senyawa nitrogen yang mana pada suhu dan tekanan normal berada dalam bentuk gas dan membentuk kesetimbangan dengan amonium. Kesetimbangan antara gas amonia dengan amonium ditunjukkan dalam persamaan reaksi:

$$
\mathrm{NH}_{3}+\mathrm{H}_{2} \mathrm{O} \rightarrow \mathrm{NH}_{4}^{+}+\mathrm{OH}^{-}
$$

Amonia yang terukur di perairan berupa amonia total $\left(\mathrm{NH}_{3}\right.$ dan $\left.\mathrm{NH}_{4}{ }^{+}\right)$. Amonia bebas $\left(\mathrm{NH}_{3}\right)$ tidak dapat terionisasi, sedangkan amonium $\left(\mathrm{NH}_{4}{ }^{+}\right)$ dapat terionisasi. Amonia bebas $\left(\mathrm{NH}_{3}\right)$ yang tidak terionisasi bersifat toksik terhadap organisme akuatik. Toksisitas amonia terhadap organisme akuatik akan meningkat jika terjadi penurunan kadar oksigen terlarut, $\mathrm{pH}$ dan suhu. Amonia dalam air permukaan berasal dari air seni, tinja serta penguraian zat organik secara mikrobiologis yang berasal dari air alam atau air buangan industri ataupun limbah domestik ${ }^{(16)}$. Amonia dijadikan salah satu indikator penyebab bau dalam air limbah industri nata de coco.

Pengolahan tersier untuk menghilangkan polutan salah satunya amonia dalam air limbah dapat dilakukan dengan tiga cara antara lain porses oksidasi, filtrasi membran dan adsorpsi. Adsorpsi diketahui merupakan metode yang paling efisien untuk menghilangkan warna, bau, 
minyak, dan organik dari air limbah(17). Adsorben yang digunakan dalam penelitian ialah $\mathrm{SiC}$ dengan variasi $\mathrm{SiO}_{2}: \mathrm{C}$ 1:3 dan 5:3. Penjerapan amonia oleh permukaan SiC berimplikasi pada potensi penurunan gas amonia dari air limbah artinya adsorben $\mathrm{SiC}$ berpotensi mengurangi bau air limbah.

\subsubsection{Variasi Rasio Adsorben}

Variasi adsorben $\mathrm{SiO}_{2}: \mathrm{C}$ yang digunakan adalah 1:3 (SiC 136) dan 5:3 ( $\mathrm{SiC} 536$ ). Tabel 3 menunjukkan bahwa rasio $\mathrm{SiO}_{2}: \mathrm{C}$ yang paling optimum untuk mengadsorpsi amonium adalah 1:3 (SiC 136). SiC 136 menunjukkan amonium teradsorpsi mencapai $45,00 \%$ dengan kapasitas adsorpsi 0,47 mg/g (massa adsorben 0,1 g dalam air limbah simulasi $10 \mathrm{~mL}$ ). Jika dibandingkan dengan kapasitas adsorpsi kontrol yaitu karbon, nilai kapasitas adsorpsi SiC 136 lebih kecil. Efisiensi adsorpsi amonium oleh kontrol sebesar 63,69 \% dengan kapasitas adsorpsi 0,66 mg/g.

Tabel 3. Perbandingan rasio adsorben $\mathrm{SiO}_{2}: \mathrm{C}$ pada adsorpsi amonium

\begin{tabular}{ccccc}
\hline $\begin{array}{c}\text { Rasio } \\
\mathbf{S i O}_{2}: \mathbf{C}\end{array}$ & $\begin{array}{c}\mathrm{Co} \\
(\mathbf{m g} / \mathbf{L})\end{array}$ & $\begin{array}{c}\mathrm{Ce} \\
(\mathbf{m g} / \mathbf{L})\end{array}$ & $\begin{array}{c}\mathrm{qE} \\
(\mathbf{m g} / \mathbf{L})\end{array}$ & $\begin{array}{c}\% \\
\text { Amoniur } \\
\text { teradsorp: }\end{array}$ \\
\hline 136 & 10,68 & 5,87 & 4,81 & 45,00 \\
536 & 10,68 & 7,60 & 3,08 & 28,86 \\
Kontrol & 10,68 & 3,88 & 6,80 & 63,69 \\
\hline
\end{tabular}

Keterangan:

Co: Konsentrasi amonia sebelum adsorpsi

Ce: Konsentrasi amonia setelah adsorpsi

qE: Konsentrasi amonia teradsorpsi

\subsubsection{Variasi Massa Adsorben}

Variasi massa adsorben yang digunakan adalah 0,$05 ; 0,1 ; 0,2 ;$ dan $0,3 \mathrm{~g}$. Penentuan massa adsorben bertujuan mengetahui massa adsorben optimum yang dibutuhkan untuk mengadsorpsi amonium secara maksimum sampai tercapai keadaan jenuh. Tabel 4 menunjukkan bahwa massa adsorben optimum adalah $0,1 \mathrm{~g}$ dengan amonium teradsorpsi $41,77 \%$. Pada massa adsorben $0,2 \mathrm{~g}$ terjadi penurunan konsentrasi amonium teradsorpsi. Hal ini dimungkinkan karena konsentrasi amonium teradsorpsi pada permukaan SiC lebih besar dibandingkan konsentrasi amonium yang tersisa dalam larutan. Sehingga perbedaan konsentrasi tersebut menyebabkan amonium yang telah terikat terdesorpsi kembali ke fasa larutan. Kondisi optimum adsorpsi tercapai pada massa adsorben 0,1 $\mathrm{g}$ dengan konsentrasi amonium teradsorpsi $4,46 \mathrm{mg} / \mathrm{L}$. Pada tahap selanjutnya digunakan massa adsorben $0,1 \mathrm{~g}$.
Tabel 4 Massa adsorben optimum pada adsorpsi amonium

\begin{tabular}{ccccc}
\hline $\begin{array}{c}\text { Massa } \\
(\mathbf{g})\end{array}$ & $\begin{array}{c}\mathrm{Co} \\
(\mathbf{m g} / \mathrm{L})\end{array}$ & $\begin{array}{c}\mathrm{Ce} \\
(\mathbf{m g} / \mathbf{L})\end{array}$ & $\begin{array}{c}\mathrm{qE} \\
(\mathbf{m g} / \mathrm{L})\end{array}$ & $\begin{array}{c}\text { \% Amonia } \\
\text { teradsorpsi }\end{array}$ \\
\hline 0,0536 & 10,68 & 9,62 & 1,06 & 9,97 \\
0,1096 & 10,68 & 6,22 & 4,46 & 41,77 \\
0,2131 & 10,68 & 7,07 & 3,61 & 33,84 \\
0,3080 & 10,68 & 6,66 & 4,02 & 37,61 \\
\hline
\end{tabular}

Keterangan:

Co: Konsentrasi amonia sebelum adsorpsi

Ce: Konsentrasi amonia setelah adsorpsi

qE: Konsentrasi Amonia teradsorpsi

\subsubsection{Variasi Konsentrasi Optimum}

Variasi konsentrasi air limbah simulasi yang digunakan adalah $10 ; 20 ; 30 ; 40 ; 50$ dan 60 $\mathrm{mg} / \mathrm{L}$ dengan volume air limbah $10 \mathrm{~mL}$ dan kontak proses selama 15 menit. Gambar 10 menunjukkan bahwa konsentrasi $\mathrm{NH}_{4} \mathrm{OH}$ optimum dengan rasio $\mathrm{SiO}_{2}: \mathrm{C} 136$ ( $\mathrm{SiC} 136$ ), massa adsorben $0,1 \mathrm{~g}$, volume air limbah simulasi $10 \mathrm{~mL}$, kecepatan pengadukan $100 \mathrm{rpm}$ dan waktu kontak 15 menit adalah $20 \mathrm{mg} / \mathrm{L}$ dengan $\%$ amonium teradsorpsi $46,25 \%$.

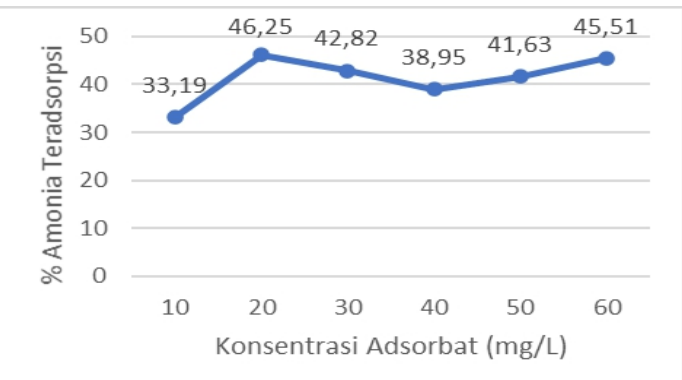

Gambar 10 Grafik variasi konsentrasi air limbah simulasi terhadap amonium teradsorpsi

\subsubsection{Penentuan Pola Isoterm Adsorpsi}

Penentuan isoterm dilakukan dengan variasi rasio adsorben $\mathrm{SiO}_{2}: \mathrm{C}$ optimum, massa adsorben optimum, dan konsentrasi limbah simulasi optimum. Isoterm digunakan untuk memprediksi kebutuhan adsorben mencapai nilai konsentrasi tertentu adsorbat ${ }^{(18)}$. Hubungan kesetimbangan antara potensial kimia adsorbat di permukaan adsorben pada suhu tetap disebut isoterm adsorpsi. Tipe isoterm adsorpsi yang dapat digunakan untuk mempelajari karakteristik adsorpsi fase cair-padat adalah persamaan isoterm Freundlich dan Langmuir.

Tujuan dari penentuan isoterm adalah mengetahui mekanisme adsorpsi dari adsorben $\mathrm{SiC}$ dalam mengadsorpsi amonium. Apakah proses adsorpsi cenderung adsorpsi kimia atau 
adsorpsi fisika. Setiap adsorben memiliki pola isoterm adsorpsi berbeda-beda karena proses adsorpsi dipengaruhi oleh banyak faktor antara lain ukuran molekul adsorbat, kepolaran zat adsorbat, suhu, ukuran adsorben, kemurnian adsorben, $\mathrm{pH}$, dan waktu kontak ${ }^{(19)}$. Gambar 11 menyajikan penentuan adsorpsi kimia atau fisika berdasarkan isoterm Langmuir dan isoterm Freundlich.

Gambar 11.(a) menunjukkan isoterm Langmuir dengan nilai $R^{2}=0,2213$. Sedangkan Gambar 11.(b) menunjukkan isoterm Freundlich dengan nilai $R^{2}=0,9450$. Berdasarkan data koefisien korelasi $\left(R^{2}\right)$ tersebut dapat diketahui bahwa adsorpsi amonium oleh $\mathrm{SiC}$ lebih mengikuti model Freundlich dari pada Langmuir karena pada pola isoterm Freundlich menunjukan $\mathrm{R}^{2}$ mendekati 1.

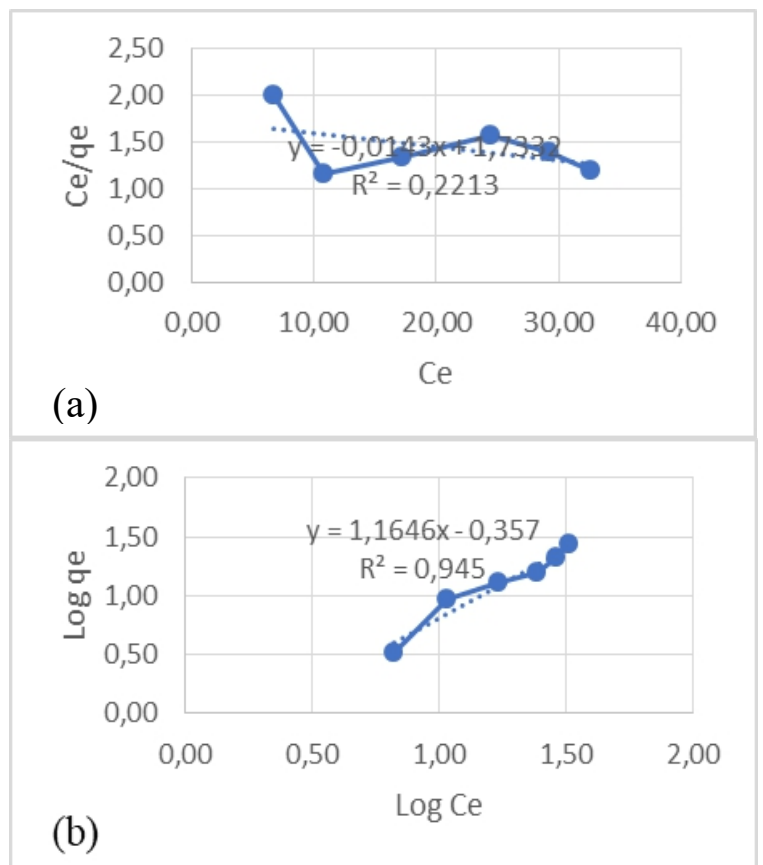

Gambar 11 Grafik pola isoterm Langmuir (a) Pola isoterm Freundlich (b) dalam adsorpsi amonium

Pada Isoterm Freundlich, adsorpsi amonium oleh adsorben $\mathrm{SiC}$ terjadi secara fisik dan membentuk lebih dari satu lapisan (multilayer), sebuah proses di mana jumlah zat terlarut yang diadsorpsi per unit adsorben massa meningkat secara bertahap ${ }^{(20)}$ dan permukaan adsorben bersifat heterogen. Pada adsorpsi fisik adsorbat tidak terikat kuat pada permukaan adsorben sehingga adsorbat dapat bergerak dari suatu bagian permukaan ke permukaan yang lain, dan pada permukaan yang ditinggalkan oleh adsorbat dapat digantikan oleh adsorbat yang lainnya. Adsorpsi fisik ini terjadi karena adanya gaya Van Der Waals yaitu gaya tarik menarik yang lemah antara adsorbat dengan permukaan adsorben.

\section{KESIMPULAN}

Berdasarkan penelitian yang telah dilakukan, maka dapat disimpulkan silika dari sabut kelapa dan karbon serbuk gergaji kayu Sengon dapat dijadikan raw material dalam pembuatan adsorben SiC. Adsorben SiC 136 dan SiC 536 memiliki fasa 3C-SiC (struktur kubik) dengan morfologi permukaan berpori sehingga SiC dapat diaplikasikan sebagai adsorben. Adsorben SiC 136 memberikan adsorpsi optimum terhadap penurunan konsentrasi amonium sebesar $45 \%$ di mana amonium merupakan salah satu parameter sumber bau pada air limbah. Proses adsorpsi amonium oleh SiC 136 lebih mengikuti pola isoterm Freundlich yang berarti proses adsorpsi berlangsung secara fisika.

\section{PERSANTUNAN}

Penulis mengucapkan terima kasih kepada Kementerian Riset dan Teknologi/BRIN sebagai pemberi beasiswa yaitu beasiswa Saintek, serta terima kasih kepada teman-teman yang telah membantu dalam menyelesaikan penelitian ini. Semua penulis makalah ini adalah sebagai kontributor utama publikasi.

\section{DAFTAR PUSTAKA}

1. Calle, F., Rosillo, P. Groot, S. L. Hemstock, \& Wood. (2012). The Biomass Assessment Handbook: Bioenergy for a Sustainable Environment, London: Earthscan.

2. Badan Pusat Statistik [BPS]. (2020). Produksi Kelapa Menurut Provinsi di Indonesia: Direktorat Jenderal Perkebunan.

3. Amin, S. (2009). Cocopreneurship. Aneka Peluang Bisnis dari Kelapa. Yogyakarta: Lily Publisher.

4. Nuswantara, L.K., Sunarso, Arifin, M. dan Setiadi, A. (2020). Komponen serat sabut kelapa yang difermentasi menggunakan mikroba pencerna serat dari rumen kerbau. Jurnal Agripet. 20(1), 1-8.

5. Anuar, M.F., Fena Y.W., Zaida M.H.M., Matoria K.A., Khaidir R.E.M. (2018). Synthesis and structural properties of coconut husk as potential silica source. Results in Physics. 11, 1-4.

6. Badan Pusat Statistik [BPS]. (2013). Produksi Serbuk Gergaji Kayu di Indonesia: Direktorat.

7. Guo, X., Zhu, L., Li, W., Yang, H. 2013. Preparation of SiC powders by carbothermal 
reduction with bamboo charcoal as renewable carbon source. Journal of Advanced Ceramics. 2, 128-134.

8. Sulaeman, A.S., Sugianto, Maddu, A. (2019). Sintesis dan Karakterisasi Silicon Carbide (SiC) dari Sekam Padi Menggunakan Metode Reduksi Magnesiotermik. Jurnal Fisika Flux, Edisi Khusus 1(1), 47-53.

9. Hakimi, Rini dan Budiman, D. (2006). Aplikasi Produksi Bersih (Cleaner Production) pada Industri Nata De Coco. Jurnal Teknik Mesin. 3 (2), 90-98.

10. Pambayun, R. (2002). Teknologi Pengolahan Nata De Coco, Yogyakarta: Kanisius.

11. Suparman. (2010). Sintesis Silikon Karbida (SiC) dari Silika Sekam Padi dan Karbon Kayu dengan Metode Reaksi Fasa Padat. Tesis, Sekolah Pascasarjana Institut Pertanian Bogor.

12. Rampe, M.J., Setiaji, B., Trisunaryanti, W. \& Triyono. (2010). The Effect of Temperature on the Crystal Growth of Coconut Shell Carbon, Proceeding, The third International Conference.

13. Sadique, S.E. (2010). Production and Purification of Silicon by Magnesiothermic Reduction of Silica Fume. Thesis, Department of Material Science and Engineering, University of Toronto.

14. Su, J., Gao, B., Chen, Z., Fu, J., An, W., Peng, X., Zhang, X., Wang, L., Huo, K., \& Chu, P.K. (2016). Large-Scale Synthesis and Mechanism of $\beta$-SiC Nanoparticles from Rice Husks by Low-Temperature Magnesiothermic Reduction. ACS Sustainable Chemistry and Engineering, 4(12), 6600-6607.

15. Kriener, M., Muranaka, T., Kato, T., Ren, Z.A., Akimitsu, J. and Maeno, Y. (2008). Superconductivity in heavily boron-doped silicon carbide. Science and Technology of Advanced Materials. 9.10.1088/14686996/9/4/044205.

16. Said, N.I. dan Sya'bani, M.R. (2014). Penghilangan Amoniak di Dalam Air Limbah Domestik dengan Proses Moving Bed Biofilm Reactor (MBBR). JAI, 7(1).

17. Murti, R.S., Purwanti, C.M.H., Suyatini. (2013). Adsorpsi Amonia dari Limbah Cair Industri Penyamakan Kulit Menggunakan Abu Terbang Bagas. Majalah Kulit, Karet dan Plastik(. 29, 85-90.

18. Alaerts G., \& Santika, S.S. 1984. Metode Penelitian Air. Usaha Nasional. Surabaya, Indonesia.

19. Wijayanti, I.E., Kurniawati, E.A. 2019. Studi Kinetika Adsorpsi Isoterm Persamaan Langmuir Dan Freundlich Pada Abu Gosok Sebagai Adsorben. EduChemia (Jurnal Kimia dan Pendidikan). 4 (2).

20. Chung, H.K., Kim, W.H., Park, J., Cho, Jinwoo., Jeong, T.Y., \& Park, P.K., (2015). Application of Langmuir and Freundlich Isotherms to Predict Adsorbate Removal Efficiency or Required Amount of Adsorbent. Korea: Journal of Environmental Engineering, Yonsei University. 